\title{
PENGARUH DANA DESA TERHADAP KEMISKINAN DI ACEH
}

\section{THE EFFECT OF VILLAGE FUNDS ON POVERTY IN ACEH}

\author{
Heru Syah Putra \\ PKP2A IV LAN ACEH
}

\begin{abstract}
ABSTRAK
Dana desa meningkatkan kapasitas fiskal desa sehingga dapat digunakan untuk kesejahteraan masyarakat. Pengalokasian dan pemanfaatan yang tepat dapat mengurangi permasalahan desa, seperti kemiskinan. Akan tetapi, peningkatan dana desa belum sepenuhnya menunjukkan keberhasilan terhadap kondisi kemiskinan. Oleh sebab itu, penelitian ini bertujuan untuk mengkaji pengaruh dana desa terhadap kemiskinan di Aceh. Sebanyak 13 kabupaten/kota di Aceh diobservasi selama tiga tahun yaitu 2015 sampai 2017. Pengujian data dilakukan dengan menggunakan analisis regresi linear. Hasil penelitian menunjukkan bahwa peningkatan dana desa berpengaruh signifikan terhadap penurunan tingkat kemiskinan di Aceh. Peningkatan dana desa sebesar 1 persen dapat mengurangi tingkat kemiskinan di Aceh sebesar 0,316 persen. Hasil estimasi tersebut signifikan pada level 95 persen. Oleh sebab itu, dana desa merupakan instrumen kebijakan yang tepat dalam pengurangan kemiskinan di Aceh.
\end{abstract}

Kata Kunci: Dana Desa, Kemiskinan, Desentralisasi, Dana Transfer

\section{ABSTRACT}

Village fund increases the fiscal capacity of a village which can be used for increasing community welfare. Appropriate allocation and utilization can reduce village problems, such as poverty. However, increasing village funds is not fully followed by the decresing of poverty rate. The lack of study regarding the linkage of village fund and poverty encourage this study. Therefore, this study aims to examine the effect of village funds on poverty in Aceh. A total of 13 districts/cities in Aceh is observed for three years, from 2015 to 2017. This study uses linear regression analysis for panel data. The result shows that increasing village funds has a significant effect on reducing poverty in Aceh. A 1 percent increase in village funds can reduce the poverty rate by 0.316 percent in Aceh. The estimated results are significant at the 95 percent level. Therefore, village funds is an effective policy to reduce poverty in Aceh.

Keywords: Village Fund, Poverty, Desentralization, Government Transfer

\section{A. PENDAHULUAN}

Kemiskinan di Indonesia
mengalami penurunan yang cukup
signifikan di tahun 2018. Untuk pertama
kali Indonesia mampu menekan angka
kemiskinan dibawah 10 persen (BPS,2018).
Penurunan ini diyakini akibat adanya
beberapa kebijakan kemiskinan yang telah
berhasil menurunlan angka kemiskinan
secara signifikan. Pemerintah Indonesia
telah mendorong berbagai kebijakan
pengentasan kemiskinan di daerah.

Pemberian bantuan sosial tunai dari pemerintah dianggap mampu mengurangi kemiskinan pada level desa dan kota. Distribusi Program beras sejahtera (Rastra) dan Bantuan Pangan Non Tunai (BPNT) pada juga diyakini berdampak positif terhadap pengurangan kemiskinan di desadesa seluruh Indonesia.

Keberhasilan dalam penurunan kemiskinan di Indonesia tidak merata antar kabupaten/kota di Indonesia. Perbedaan ini diyakini akibat adanya perbedaan kapasitas 
daerah dalam menjalankan kebijakankebijakan kemiskinan. Pemilihan kegiatan yaitu pada modal atau padat karya, misalnya, akan sangat mempengaruhi keberhasilan dalam pengentasan kemiskinan. Selain itu, perbedaan potensi daerah juga mempengaruhi kemisikinan di Indonesia. Investasi baik luar dan dalam negeri juga mempengaruhi keberhasilan pengurangan kemiskinan di suatu daerah.

Peningkatan kapasitas fiskal daerah seharusnya mampu mendorong kebijakan pengentasan kemiskinan lebih cepat. Selain ketersedian DAU dan DAK, kebijakan desentralisasi fiskal pada level desa yaitu pemberian dana desa juga seharusnya mampu mengatasi kemiskinan di level terdepan yaitu desa. Pada tahun 2017, Pemerintah Indonesia telah mengalokasikan dana desa 60 terliun Rupiah yang tersebar ke 74.954 desa di Indonesia.

Salah satu provinsi yang mendapat dana desa adalah Aceh. Pada tahun 2017, total dana desa yang diperoleh Aceh sebesar 4,8 triliaun rupiah yang tersebar ke 6.497 desa. Potensi dana desa tersebut diharapakan mampu menjadi solusi bagi tingginya kemiskinan di Aceh. Pada tahun 2017, Aceh menduduki peringkat termiskin di pulau Sumatera. Kondisi ini menjadi pertanyaan besar yaitu kapasitas fiskal, baik di provinsi, kabupaten/kota, dan desa belum kelihatan mampu melepaskan Aceh dari kemiskinan.

Keraguan akan manfaat dana desa terhadap kebijakan kesejahteraan masyarakat khususnya penanganan kemiskinan diyakini akibat belum memadainya kapasitas dan kapabilitas pemerintah desa (Aziz, 2016). Selain itu, belum terlibatnya peran serta masyarakat secara aktif dalam pengelolaan dana desa juga sangat mempengaruhi manfaat dana desa. Padahal, akuntabilitas pengelolaan keuangan alokasi dana desa, kebijakan desa, dan kelembagaan desa berpengaruh langsung kesejahteraan masyarakat (Dura, 2016).
Penelitian tentang hubungan desentralisasi fiskal atau tranfer pusat ke daerah terhadap kemiskinan. Transfer pusat ke daerah memberi pengaruh yang signifikan terhadap penurunan kemiskinan di daerah. Akan tetapi, penelitian yang melihat secara makro pengaruh dana desa terhadap kemiskinan di kabupaten/kota Aceh belum pernah dilakukan. Peningkatan alokasi dana desa belum sepenuhnya berdampak pada pengurangan pengangguran di kabupaten/kota di Aceh. Bahkan, beberapa daerah menunjukkan pertumbuhan pengangguran. Oleh sebab itu, penelitian ini bertujuan menjawab fenomena tersebut penelitian. Adapun masalah penelitian ialah bagaimana pengaruh dana desa terhadap kemiskinan di Aceh? Adapun tujuan penelitian yaitu mengetahui pengaruh dana desa terhadap kemiskinan di Aceh.

\section{B. KAJIAN PUSTAKA}

\section{Kemiskinan}

Kemiskinan tidak dapat hanya diukur dengan satu indikator. Kemiskinan tidak hanya terkait dengan pendapatan atau pengeluaran harian seseorang atau rumah tangga. Kemiskinan memiliki arti dan dimensi yang luas. Kemiskinan dapat dikelompokkan menjadi tiga jenis; kemiskinan absolut (pendapatan dan konsumsi), kemiskinan relatif (fasilitas publik), dan kemiskinan sosial (Khan, 2016). Kemiskinan absolut, atau lebih dikenal dengan kemiskinan dengan pendekatan pendapatan/penghasilan, kemiskinan yang disebabkan seseorang tidak mampu memenuhi standar minimum pendapatan yang telah ditetapkan. Worl Bank telah menetapkan garis kemiskinan (poverty line) sebesar besar US \$ 1 per hari. Setelah itu, World Bank telah mengubah garis kemiskinan dua kali pada tahun 2005 dan 2011 menjadi US \$ 1,25 dan US \$ 1,9. Akan tetapi, banyak negara yang menggunakan pendekatan yang berbeda dalam menentukan garis kemiskinan seperti 
Indonesia yang menggunakan standar konsumsi kalori perhari.

Kemiskinan relatif dapat diartikan sebagai kegagalan dalam mempertahankan standar hidup yang layak di dalam sebuah komunitas tertentu. Pendekatan penentuan kemiskinan relatif mempertimbangkan dua hal yaitu pendapatan/income dan kebutuhan dasar seperti pendidikan dan kesehatan (USAID, 2005). Kemiskinan relatif juga dapat diartikan sebagai ketidakmampuan seseorang untuk menikmati fasilitas barang dan jasa publik yang telah disediakan oleh pemerintah baik yang bersifat gratis maupun yang telah disubsidi. Sedangkan kemiskinan kemampuan (capabilities deprivation) lebih mengarah ketidakmampuan seseorang dalam kehidupan bermasyarakat. Definisi ini diperkenalkan oleh Sen (World Bank Institute 2005) yang menyimpulkan bahwa kemampuan diartikan sebagai kemampuan untuk mencapai sesuatu.
Ciri-ciri kelompok (penduduk) miskin bisa digolongkan sebagai berikut (Suryawati, 2005) :

1. Rata-rata tidak mempunyai faktor produksi sendiri seperti tanah, modal, peralatan kerja, dan keterampilan

2. Mempunyai tingkat pendidikan yang rendah,

3. Kebanyakan bekerja atau berusaha sendiri dan bersifat usaha kecil (sektor informal), setengah menganggur atau menganggur (tidak bekerja)

4. Kebanyakan berada di pedesaan atau daerah tertentu perkotaan (slum area), dankurangnya kesempatan untuk memperoleh (dalam jumlah yang cukup): bahan kebutuhan pokok, pakaian, perumahan, fasilitas kesehatan, air minum, pendidikan, angkutan, fasilitas komunikasi, dan kesejahteraan sosial lainnya.

Gambar 1. Perangkap Kemiskinan (Poverty Trap) (Suryawati, 2005)

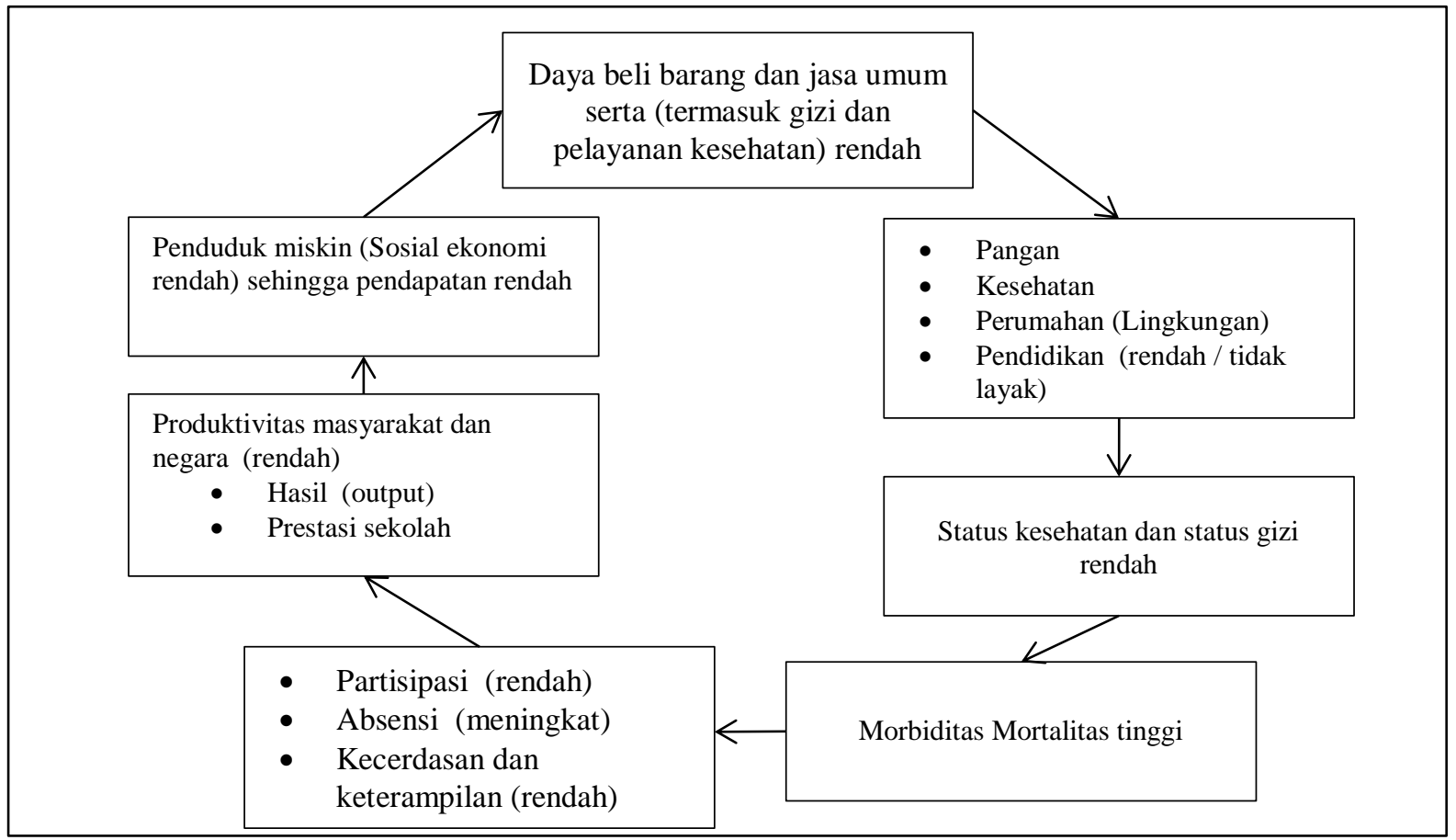


Perangkap kemiskinan (poverty trap) sulit kali dilepas karena kondisi kemiskinan membuat individu dan rumah tangga menjadi semakin rentang dan semakin tidak berdaya keluar dari kemiskinan.

\section{Desentralisasi Fiskal}

Desentralisasi diartikan sebagai pergeseran otoritas dan tanggung jawab dari pemerintah pusat ke pemerintah daerah. Dalam penerapannya, pergeseran itu tidak hanya terjadi pada pemerintah lokal tetapi juga banyak organisasi seperti pemerintah daerah dan organisasi nonpemerintah swasta atau sukarela (Khan, 2013). Di beberapa negara maju, penyediaan barang publik telah dialihkan ke organisasi swasta. Selanjutnya, desentralisasi pada dasarnya dibagi menjadi tiga jenis; dekonsentrasi atau desentralisasi administrasi, devolusi atau desentralisasi demokratis, dan desentralisasi fiskal. Dekonsentrasi atau desentralisasi administrasi berarti pergeseran tanggung jawab administratif dari pemerintah pusat kepada kementerian dan lembaga pemerintahnya. Sementara devolusi atau desentralisasi adalah transfer kekuasaan dan sumber daya dari pusat ke pihak berwenang di tingkat bawah, yang merupakan perwakilan dan bertanggung jawab kepada penduduk setempat (Khan, 2016; Sudhipongpracha \& Wongpredee, 2016).

Salah satu tantangan desentralisasi yaitu perbedaan kemampuan di antara pemerintah lokal dalam sebuah negara. Desentralisasi fiskal diperlukan agar kesenjangan antar daerah dapat dikurangi. Desentralisasi fiskal adalah transfer pendapatan fiskal dan sumber fiskal dari pemerintah pusat ke pemerintah daerah. Tujuannya untuk mengurangi kesenjangan kapasitas fiskal di antara pemerintah daerah. Faktor utama untuk transfer fiskal adalah manfaat fiskal bersih (Shah, 2007).

Namun pada kenyataannya, sebagian besar pemerintah daerah tidak dapat menghasilkan dan mengumpulkan pendapatan yang cukup dari sumbersumber baru yang didelegasikan dalam sistem desentralisasi fiskal. Hal tersebut terjadi karena pengalihan kekuasaan tidak diikuti pemindahan kapabilitas pemerintah daerah. Selain itu, kapasitas administratif yang terbatas dan kondisi ekonomi lokal yang buruk (Loayza, Rigolini, \& CalvoGonzález, 2014).

Sebagian besar pemerintah pusat mengadopsi pembagian pendapatan, suatu pendekatan untuk mengurangi kesenjangan. Pendekatan ini dikenal sebagai transfer antar pemerintah (intergovernmental transfer). Pemerintah pusat mentransfer sejumlah hibah kepada pemerintah daerahnya yang tidak mampu membiayai pengeluaran mereka. Ada dua jenis transfer antar pemerintah, transfer tanpa syarat dan transfer bersyarat (Khan, 2016). Transfer tanpa syarat memberikan kewenangan penuh kepada pemerintah daerah untuk mengelola dana secara bebas tanpa intervensi pemerintah pusat. Di sisi lain, transfer bersyarat membutuhkan intervensi pemerintah pusat, mulai dari perencanaan hingga pembelanjaan. Secara praktis, pemerintah pusat memutuskan jenis kegiatan yang didanai oleh transfer bersyarat, sedangkan pemerintah daerah hanya mengikuti mekanismenya.

\section{Pengaruh Desentralisasi Fiskal terhadapKemiskinan}

Desentralisasi adalah salah satu kebijakan penting untuk memberantas kemiskinan dan deprivasi, terutama di negara berkembang (World Bank, 2005). Desentralisasi mendorong kebijakan yang lebih berpihak pada masyarakat miskin dengan membawa pembuat kebijakan lebih dekat ke masyarakat. Desentralisasi juga meningkatkan efisiensi dalam penyediaan layanan publik yaitu penyedian barang publik yang sesuai dengan keinginan masyarakat yang disesuaikan dengan daerah (Sudhipongpracha \& Wongpredee, 2016). Selanjutnya, Desentralisasi diyakini menjadi alat yang efektif untuk meningkatkan pendapatan dan akses ke 
layanan dasar. Dengan memberikan wewenang kepada pemerintah lokal untuk memutuskan jenis dan jumlah barang publik, pendekatan ini memungkinkan penyediaan barang publik yang sesuaidengan kebutuhan masyarakat.

Hubungan desentralisasi dan kemiskinan dapat dipahami dengan menyusun kerangka hubungan desentralisasi dan kemiskinan. Pertama, desentralisasi dapat mengarah pada peningkatan pertumbuhan ekonomi, yang pada gilirannya dapat mengurangi kemiskinan absolut. Kedua, penargetan regional dan efisiensi ekonomi pada saat yang sama juga dapat meningkat dalam penyediaan layanan publik yang lebih baik, yang dapat mengakibatkan penurunan kemiskinan relatif. Ketiga, melalui peningkatan partisipasi dan perwakilan, desentralisasi dapat memberdayakan orang-orang yang miskin dan kurang beruntung dalam proses pengambilan keputusan.

Gambar 2. Hubungan Desentralisasi dan Kemiskinan, (Khan, 2016)

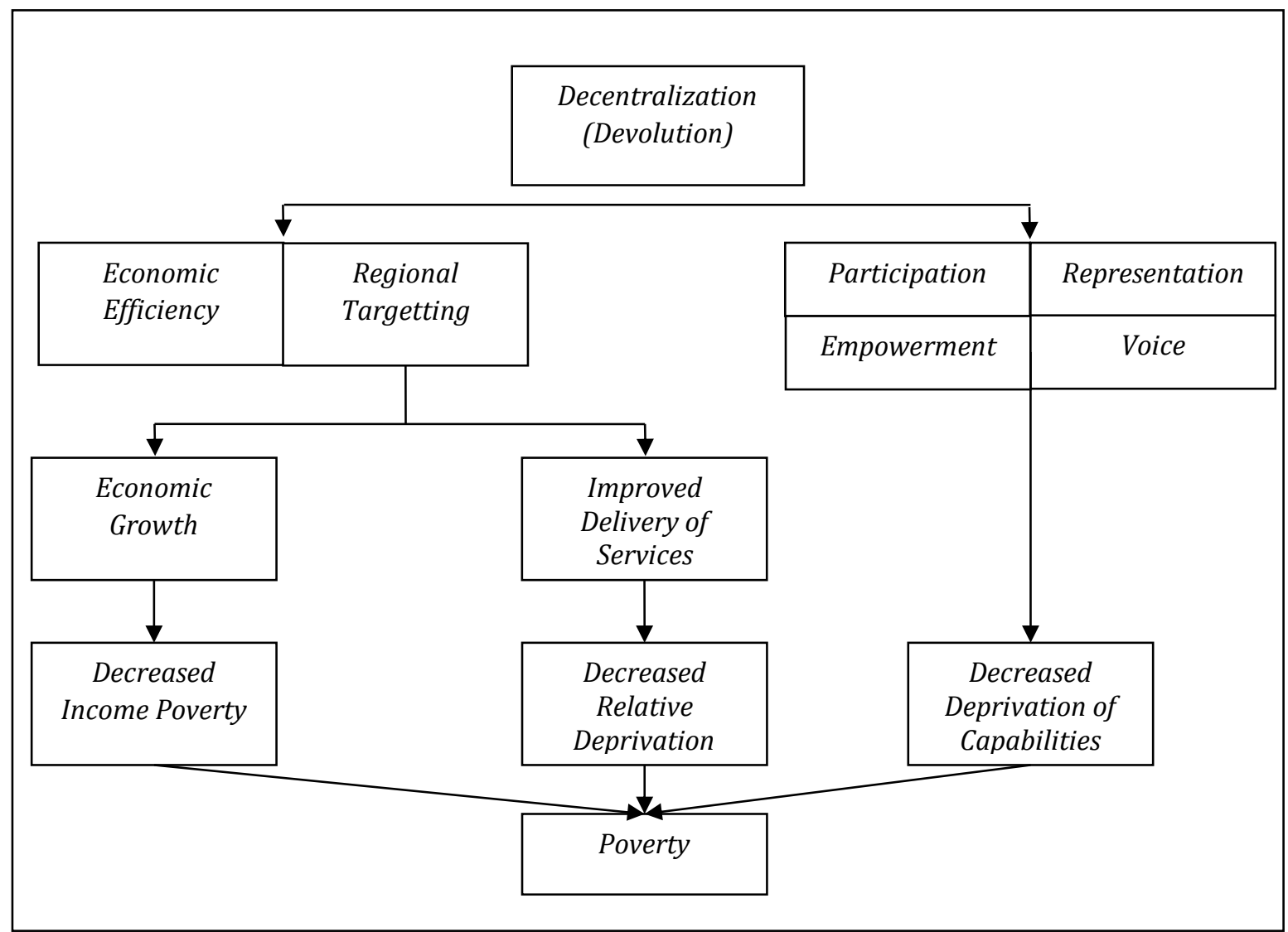

\section{Kebijakan Dana Desa di Indonesia}

Dana Desa adalah dana yang bersumber dari Anggaran Pendapatan dan Belanja Negara yang diperuntukkan bagi Desa yang ditransfer melalui Anggaran Pendapatan dan Belanja Daerah kabupaten/kota dan digunakan untuk membiayai kegiatan penyelenggaraan pemerintahan, pelaksanaan pembangunan, pembinaan kemasyarakatan, dan pemberdayaan masyarakat. Oleh sebab itu, Dana desa dapat digunakan untuk membiayai kegiatan penyelenggaraan pemerintahan, pelaksanaan pembangunan, pembinaan kemasyarakatan, dan pemberdayaan masyarakat. Alur Penganggaran, Pengalokasian, dan Penyaluran Dana Desa telah diatur dalam Peraturan Menteri Keuangan Nomor 49/PMK.07/2016 tentang Tata Cara Pengalokasian, Penyaluran, Penggunaan, 
Pemantauan dan Evaluasi Dana Desa. Penjelasan sebagai berikut:

- Penganggaran Dana Desa Setiap Kabupaten/Kota; Direktorat Jenderal Perimbangan Keuangan menyusun Indikasi Kebutuhan Dana dan Rencana Dana Pengeluaran Dana Desa dengan memperhatikan persentase Dana Desa yang ditetapkan dalam peraturan perundang-undangan dan kinerja pelaksanaan Dana Desa menjadi dasar penganggaran Dana Desa. Berdasarkan penganggaran dana desa ini, Dirjen Perimbangan Keuangan melakukan penghitungan rincian Dana Desa setiap kabupaten/kota

- Pengalokasian Dana Desa Setiap Desa: Berdasarkan rincian Dana Desa setiap kabupaten/kota, bupati/walikota menghitung rincian Dana Desa setiap Desa. Tata cara pembagian dan penetapan besaran Dana Desa ditetapkan dengan peraturan bupati/walikota daerah masingmasing.

- Penyaluran Dana Desa: Dana Desa disalurkan oleh Pemerintah kepada kabupaten/ kota. Penyaluran Dana Desa dilakukan dengan cara pemindahbukuan dari Rekening Kas Umum Negara (RKUN) ke Rekening Kas Umum Daerah (RKUD). Kemudian, Dana Desa tersebut disalurkan oleh kabupaten/kota kepada Desa

Gambar 3. Sumber Pendapatan Desa (Diolah penulis)

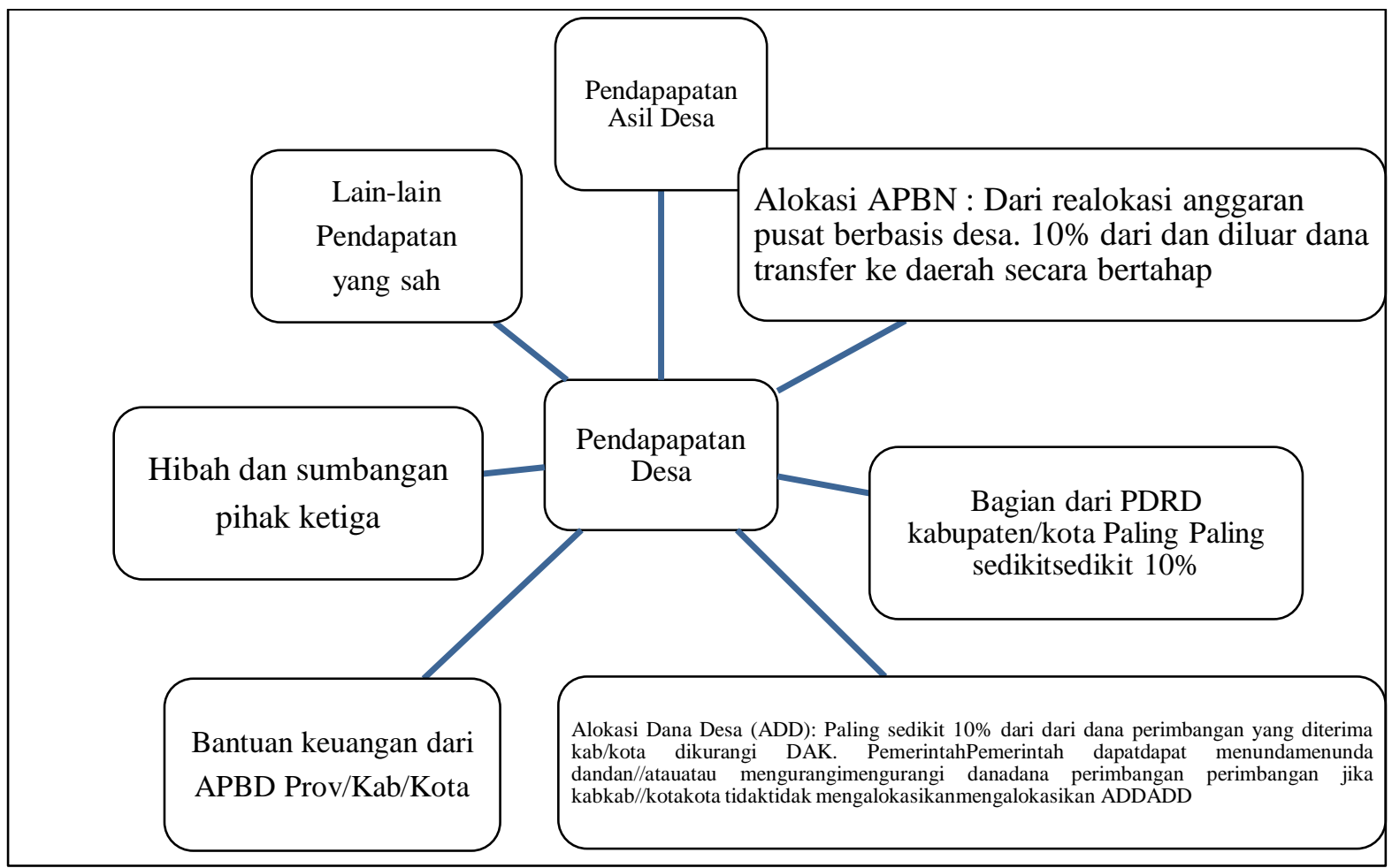




\section{METODE PENELITIAN}

Penelitian ini menggunakan data tingkat kabupaten yaitu 13 kabupaten dan kota yang diamati di Aceh. Semua data diperoleh melalui situs web resmi Bank Dunia, Badan Pusat Statistik, dan Kementerian Keungan. Data kemiskinan yang digunakan adalah data kemiskinan dengan pendekatan BPS yang telah disajikan oleh BPS di website resmi BPS maupun website World Bank.

Penelitian ini menggunakan model regresi linier untuk memperkirakan pengaruh dana desa terhadap kemiskinan di Aceh. Pendekatan regresi linear telah digunakan secara luas oleh para peneliti yang mengkaji dampak desentralisasi terhadap kemiskinan di suatu negara (Lewis, 2016; O'dwyer \& Ziblatt, 2006; Sudhipongpracha, 2016). Penelitian ini menggunakan analisas linera dengan fixed effect sehingga hasilyang diberikan lebih akurat dan dapat berfokus hanya variabelutama penelitian yaitu dana desa dan kemiskinan. Dengan mengasumsikan bahwa kemiskinan adalah fungsi desentralisasi, model linier dapat dibangun sebagai berikut:

$$
\operatorname{Pov}_{i t}=\beta_{0}+\beta_{1} \log D D_{i t}+\varepsilon_{i t}
$$

Variabel kemiskinan yaitu Pov yaitu Tingkat Kemiskinan yaitu jumlah penduduk miskin dibandingkan jumlah penduduk di kabupaten/kota (angka dalam persen). Sedangkan Dana Desa yaitu variabel (DD) yaitu alokasi total dana desa pertahun untuk sebauah kabupaten kota. Penelitian inijuga menggunakan variabel DAU dan DAK sebagai variabel independen sehingga mampu memberikan informasi yang lebihlengkap tentang pengaruh jenis dana transfer terhadap kemiskinan di Aceh.

\section{HASIL}

Hasil penelitian menunjukkan bahwa peningkatan dana desa tidak selalu diikuti oleh penurunan penduduk miskin di Aceh selama tahun 2015 sampai 2017. Pada tahun 2017, misalnya, kenaikan dana desa belum mampu menurunkan penduduk miskin di Kabupaten Simeulue. Peningkatan 26,79 persen dana desa tidak berdampak langsung terhadap penurunan kemiskinan, bahkan terjadi peningkatan penduduk miskin menjadi 18.400 jiwa pada tahun 2017. 
Tabel 1. Perkembangan Jumlah Penduduk Miskin dan Dana Desa di Aceh (13 kabupaten/kota)

\begin{tabular}{|c|c|c|c|c|c|}
\hline $\begin{array}{c}\text { Nama } \\
\text { Wilayah }\end{array}$ & Tahun & $\begin{array}{c}\text { Jumlah } \\
\text { Penduduk } \\
\text { Miskin }\end{array}$ & Pertumbuhan & $\begin{array}{c}\text { Dana Desa } \\
(\mathbf{R p})\end{array}$ & Pertumbuhan \\
\hline \multirow[t]{3}{*}{ Simeulue } & 2015 & 18120 & - & $37.347 .391 .000,00$ & \\
\hline & 2016 & 17930 & $-1,05$ & $3.780 .058 .000,00$ & 124,33 \\
\hline & 2017 & 18400 & 2,62 & $106.228 .789 .000,00$ & 26,79 \\
\hline \multirow{3}{*}{$\begin{array}{l}\text { Aceh } \\
\text { Singkil }\end{array}$} & 2015 & 24840 & & $31.643 .403 .000,00$ & \\
\hline & 2016 & 25090 & 1,01 & 70.944.217.000,00 & 124,20 \\
\hline & 2017 & 26270 & 4,70 & $89.900 .271 .000,00$ & 26,72 \\
\hline \multirow{3}{*}{$\begin{array}{l}\text { Aceh } \\
\text { Selatan }\end{array}$} & 2015 & 29610 & & $68.915 .039 .000,00$ & \\
\hline & 2016 & 30680 & 3,61 & $154.542 .183 .000,00$ & 124,25 \\
\hline & 2017 & 32510 & 5,96 & $197.045 .391 .000,00$ & 27,50 \\
\hline \multirow{3}{*}{$\begin{array}{l}\text { Aceh } \\
\text { Tenggara }\end{array}$} & 2015 & 30140 & & $100.335 .885 .000,00$ & \\
\hline & 2016 & 29390 & $-2,49$ & $225.023 .540 .000,00$ & 124,27 \\
\hline & 2017 & 30840 & 4,93 & $286.814 .473 .000,00$ & 27,46 \\
\hline \multirow[t]{3}{*}{ Aceh Timur } & 2015 & 63480 & & $134.684 .927 .000,00$ & \\
\hline & 2016 & 61630 & $-2,91$ & $302.065 .821 .000,00$ & 124,28 \\
\hline & 2017 & 63670 & 3,31 & $384.626 .960 .000,00$ & 27,33 \\
\hline \multirow{3}{*}{$\begin{array}{l}\text { Aceh } \\
\text { Tengah }\end{array}$} & 2015 & 34260 & & $77.468 .513 .000,00$ & \\
\hline & 2016 & 33160 & $-3,21$ & $173.740 .512 .000,00$ & 124,27 \\
\hline & 2017 & 34240 & 3,26 & $221.075 .321 .000,00$ & 27,24 \\
\hline \multirow[t]{3}{*}{ Aceh Barat } & 2015 & 41360 & & $84.303 .641 .000,00$ & \\
\hline & 2016 & 40110 & $-3,02$ & $189.083 .713 .000,00$ & 124,29 \\
\hline & 2017 & 40720 & 1,52 & $240.736 .847 .000,00$ & 27,32 \\
\hline \multirow[t]{3}{*}{ Aceh Besar } & 2015 & 62270 & & $156.476 .096 .000,00$ & \\
\hline & 2016 & 62030 & $-0,39$ & $350.971 .062 .000,00$ & 124,30 \\
\hline & 2017 & 62720 & 1,11 & $447.113 .772 .000,00$ & 27,39 \\
\hline \multirow[t]{3}{*}{ Pidie } & 2015 & 88220 & & $189.166 .786 .000,00$ & \\
\hline & 2016 & 90160 & 2,20 & $424.095 .116 .000,00$ & 124,19 \\
\hline & 2017 & 92340 & 2,42 & $542.393 .270 .000,00$ & 27,89 \\
\hline \multirow[t]{3}{*}{ Bireuen } & 2015 & 73140 & & $158.871 .893 .000,00$ & \\
\hline & 2016 & 70440 & $-3,69$ & $356.336 .571 .000,00$ & 124,29 \\
\hline & 2017 & 71540 & 1,56 & $453.877 .914 .000,00$ & 27,37 \\
\hline \multirow[t]{3}{*}{ Aceh Utara } & 2015 & 111440 & & $561.531 .420 .000,00$ & \\
\hline & 2016 & 115050 & 3,24 & $498.839 .552 .000,00$ & $-11,16$ \\
\hline & 2017 & 118740 & 3,21 & $635.314 .441 .000,00$ & 27,36 \\
\hline \multirow{3}{*}{$\begin{array}{l}\text { Aceh Barat } \\
\text { Daya }\end{array}$} & 2015 & 25930 & & $35.865 .784 .000,00$ & \\
\hline & 2016 & 25730 & $-0,77$ & $80.000 .245 .000,00$ & 123,05 \\
\hline & 2017 & 26570 & 3,26 & $116.099 .074 .000,00$ & 45,12 \\
\hline
\end{tabular}

Sumber: BPS, World Bank, dan Kementerian Keuangan (diolah)

Selama periode observasi penelitian, dari 13 kabupaten/kota yang diamati, penurunan kemiskinan tertinggi terjadi di kabupaten Bireun yaitu tahun 2016 yaitu penurunan sebesar 3,69 persen. Pada tahun tersebut, terjadi peningkatan alokasi dana desa yaitu dari 158 milyar menjadi 356 milyar dengan peningkatan sebesar 124 persen.

Pengujian pengaruh dana desa dilakukan dengan menguji secara OLS masing-masing variabel penelitian. Pertama, pengujain dilakukan terhadap pengaruh dana desa ke variabel tingkat kemiskinan di kabupaten/kota terpilih. 
Selanjutnya Uji regresi juga dilakukan untuk DAU dan DAK sehingga terlihat perbandingan besaran pengaruh masingmasing variabel.

Tabel 2. Hasil Estimasi Dana Desa, DAU,dan DAK terhadap Tingkat Kemiskinan di Aceh

\begin{tabular}{lccc}
\hline \multicolumn{1}{c}{ Variabel } & Model 1 & Model 2 & Model 3 \\
\hline Log Dana Desa & $-0.316^{* * *}$ & & \\
Log DAU & $(0.132)$ & -1.811 & \\
& & $(1.322)$ & -0.0403 \\
Log DAK & & & $(0.0305)$ \\
& & $67.01 *$ & $18.88^{* * *}$ \\
Constant & $26.03 * * *$ & $(35.91)$ & 36 \\
& $(3.505)$ & 36 & 12 \\
\hline Observations & 36 & 12 & \\
Kota/Kabupaten & 12 & &
\end{tabular}

Hasil pengujian menunjukkan bawa dana desa berpengaruh positif terhadap penurunan angka kemiskinan di kabupaten/kota di Aceh. Peningkatan dana desa sebesar 1 persen dapat mengurangi tingkat kemiskinan di Aceh sebesar 0,316 persen. Hasil estimasi tersebut signifikan pada level 95 persen. Sedangkan variabel DAK juga menunjukkan pengaruh signifikan yang sama yaitu mampu mengurangi persentase kemiskinan atau tingkat kemiskinan.

\section{E. PEMBAHASAN}

Hasil pengujian statistik menunjukkan bahwa dana desa berpengaruh positif dan signifikan terahadap kemiskinan di kabupaten/kota. Hasil yang sama ditemui dalam penelitian sebelumnya di Kabupaten Melawi (Setianingsih, 2016). Akan tetapi, sifnifikansi pengaruh dana desa berbedabeda. Alokasi pembangunan, alokasi pemberdayaan, dan alokasi pembinaan masyarakat memiliki tingakt signifikans yang berbeda. Dana desa untuk pembinaan kemasyarakatan tidak signifikan terhadap penduduk miskin hal ini dikarenakan alokasi yang sangat kecil untuk kegiatan pembinaan. Selain itu, dana desa untuk pemberdayaan masyarakat juga tidak signifikan yang disebabkan kemampuan menjalankan kegiatan pada program pemberdayaan masyarakat.

Walaupun telah menunjukkan pengaruh yang signifikan, dana desa belum berkontribusi besar terhadap penurunan kemiskinan di sebuah kabupaten/kota. Hal ini dapat disebabkan pengelolaan dana desa belum mampu meningkatkan pemberdayaan masyarakat secara keseluruhan. Penelitian tentang rendahnya pemberdayaan masyarakt dalam pengelolaan dan desa telah dilakukan di Kabupaten Lamongan. Hasilnya menunjukkan bahwa secara normatif dan administratif pengelolaan alokasi dana desa dilakukan dengan baik, namun secara substansi masih belum menyentuh makna pemberdayaan yang sesungguhnya. Selain itu, beberapa stakeholders juga belum melaksanakan perannya secara maksimal, hanya kepala desa selaku tim pelaksana yang mendominasi pengelolaan alokasi dana desa tersebut (Karimah, Saleh, \& Wanusmawatie, 2005).

Hasil penelitian ini juga menunjukkan bahwa terdapat perbedaan dampak perubahan tiga instrumen desentralisasi fisklayaitu Dana Desa, DAU, 
dan DAK. Hasil penelitian yang menemukan perbedaan dampak antar jenis dana transfer telah dikaji dalam penelitian sebelumnya (Putra, 2017). Hasil penelitian sebelumnya menunjukkan bahwa DAU memiliki efek yang lebih tinggi daripada DAK terkait pengurangan kemiskinan. Peningkatan DAU sebesar $1 \%$ akan mengurangi angka kemiskinan sebesar $0,068 \%$, sebaliknya, DAK hanya memiliki $0,0418 \%$. Upaya perbandingan telah dilakukan dalam penelitian ini dengan menguji ketiga data tersebut secara simultan, akan tetapi hasil yang didapat tidak signifikan sehingga tidak ditampilkan dalam penelitian ini.

\section{F. KESIMPULAN DAN SARAN}

Peningkatan dana desa terjadi secara signifikan di 13 kabupaten/kota di Aceh selama tahun 2015-2017. Pada tahun 2016, peningkatan rata-rata dana desa di atas 100 persen. Akan tetapi, peningkatan tersebut tidak selamanya di ikuti dengan penurunan kemiskinan. Hasil pengujian secara statistik menunjukkan bahwa peningkatan dana desa berpengaruh signifikan terhadap penurunan tingkat kemiskinan di Aceh. Peningkatan dana desa sebesar 1 persen dapat mengurangi tingkat kemiskinan di Aceh sebesar 0,316 persen. Hasil estimasi tersebut signifikan pada level 95 persen. Selain dana desa, DAK juga teruji berpengaruh terhadap kemiskinan selama periode tersebut.

\section{DAFTAR ISI}

\section{Jurnal}

Ali Khan, S. (2013). Decentralization and poverty reduction: A theoretical framework for exploring the linkages. International Review of Public Administration, 18(2), 173-210. http://doi.org/10.1080/12294659.201 3.10805256

Aziz, N. L. L. (2016). Otonomi Desa dan
Peningkatan DAK sebesar 1 persen dapat mengurangi tingkat kemiskinan di Aceh sebesar 0,0403 persen. Tingkat keyakinan koefisien tersebut juga 95 persen.

Berdasarkan hasil uji statistik, dana desa merupakan instrumen kebijakan yang tepat dalam pengurangan kemiskinan di Aceh. Peningkataan dana desa mberkontribusi terhadap pengurangan kemiskinan. Pemerintah pusat dapat meningkatkan alokasi dana desa dalam rangka pengurangan kemiskinan di Aceh. Selain dana desa, instrumen kebijakan DAK juga dapat dijadikan pilihan dalam pengurangan kemiskinan di Aceh.

\section{G. KETERBATASAN PENELITIAN}

Penelitian ini menggunakan data wilayah yang relatif sedikit yaitu hanya 13 dari 23 kabupaten/kota di Aceh. Pemanfaatan hanya 13 karena kemampuan akses peneliti yang baru mampu memperoleh data dihanya 13 kabupaten/kota tersebut. Hasil yang lebih baik pastinya dapat diperoleh dengan memperbanyak jumlah observasi maupun data rentang waktu. Selain itu, penelitian ini juga berpotensi terkena omitted variable bias mengingat penelitian ini tidak memasukan variabel makro lainnya yang mungkin juga berpengaruh terhadap kemiskinan di kabupaten/kota di Aceh. Perbaikan model penelitian dapat menjadi agenda penting untuk penelitian selanjutnya.

Efektivitas Dana Desa. Jurnal Penelitian Politik, 13(726).

Dura, J. (2016). Pengaruh Akuntabilitas Pengelolaan Keuangan Alokasi Dana Kampung, Kebijakan Kampung dan Kelembagaan Kampung Terhadap Kesejahteraan Masyarakat. Jurnal JIBEKA, 10, 26-32. 
Karimah, F., Saleh, C., \& Wanusmawatie, I. (2005). Pengelolaan Alokasi Dana Desa Dalam Pemberdayaan Masyarakat, 2(4), 597-602.

Khan, S. A. (2016). International Review of Public Administration Decentralization and Poverty Reduction : A Theoretical Framework for Exploring the Linkages EXPLORING THE LINKAGES, 4659(November). http://doi.org/10.1080/12294659.201 3.10805256

Lewis, B. D. (2016). Is Central Government Intervention Bad for Local Outcomes? Mixed Messages from Indonesia. The Journal of Development Studies, 52(2), 300-313. http://doi.org/10.1080/00220388.201 5.1068293

Loayza, N. V., Rigolini, J., \& CalvoGonzález, O. (2014). More Than You Can Handle: Decentralization And Spending Ability Of Peruvian Municipalities. Economics and

Politics,26(1),56-78. http://doi.org/10.1111/ecpo.12026

O’dwyer, C., \& Ziblatt, D. (2006). Does Decentralisation Make Government More Efficient and Effective? Commonwealth \& Comparative Politics, 44(3), 326-343. http://doi.org/10.1080/146620406009 97064
Putra, H. S. (2017). The Linkage of Intergovernmental Transfer and Poverty in Indonesia. Jurnal Bina Praja, 9(1), 29-40. http://doi.org/10.21787/jbp.09.2017.2 9-40

Setianingsih, I. (2016). Kontribusi Dana Desa Dalam Menurunkan Angka Kemiskinan Di Kabupaten Melawi. Jurnal Ekonomi Daerah, 1(3), 1-18.

Shah, A. (2007). Local public financial management. Retrieved from http://books.google.com/books

Sudhipongpracha, T. (2016). Do the poor count in fiscal decentralization policy? A comparative analysis of the general grant allocation systems in Indonesia and Thailand. Journal of Asian Public Policy, 00(00), 1-18. http://doi.org/10.1080/17516234.201 6.1195946

Sudhipongpracha, T., \& Wongpredee, A. (2016). Fiscal decentralization in comparative perspective: Analysis of the intergovernmental grant systems in Indonesia and Thailand. Journal of Comparative Policy Analysis: Research and Practice, 00(00), 1-17. http://doi.org/10.1080/13876988.201 6.1138659

Suryawati, C. (2005). Memahami Kemiskinan Secara Multi dimensional. Jurnal Manajemen Pelayanan Kesehatan, 8(3), 121-129. 